\title{
Editorial
}

\section{Never Waste a Good Crisis}

\section{The End of the WTO Dream, or the Beginning of Something Greater?}

\author{
Gabrielle Marceau* \\ University of Geneva, Geneva, Switzerland \\ Gabrielle.marceau@unige.ch
}

Today's international trade system is premised on certain fundamental principles - some specific to the WTO system, others coming from general international law - which have framed its evolution.

These principles include the equality of States; equality of norms (except for jus cogens); the specialization principle, whereby each IGO is responsible for a special subject matter; the non-discrimination principle, and, to some extent, principles of transparency, mutual supportiveness, and coherence.

One of the basic principles of the GATT system (forefather of the WTO) came from the idea of the "Club" and is reflected in the most-favoured-nation ('MFN') principle. Pursuant to this principle, tariff commitments and other benefits provided to products originating from a GATT Contracting Party were automatically extended to all other members of the GATT club, even if they had been negotiated on a bilateral basis. The "magic" effect of multilateralizing market access commitments has attracted many new members to the Club and also led to rises in living standards, growing volumes of real income, and expanded world production for nearly $5^{\circ}$ years for the Club's members. This was the dream of the founders of the GATT. That dream became reality.

* Prof Gabrielle Marceau is a Professor at the University of Geneva. The views expressed in this article have been contributed in her personal capacity and are not intended to reflect the views of the WTO Secretariat or its Members. 
In the late 1980s, a new issue emerged in international trade law and policy discussions: the call to recognize the important links between trade and the protection of health and the environment. This marked the beginning of sustained social attention to the relationship between trade and non-trade concerns, including trade and labour, trade and environment, trade and health, trade and animal welfare.

With the birth of the WTO, the doors of the old GATT opened up. The system acquired tools to address the need to foster coherence with other legal systems and other international organizations. Relying on the new WTO goal of promoting sustainable development, the Appellate Body ('AB') developed a more holistic interpretation of WTO provisions and flexibilities which emphasized the right of WTO Members to prioritize environment, health and other non-trade policies over market liberalization. It is now well established that WTO Members have non-trade concerns as well as international obligations in areas such as health and environment as provided, for instance, in GATT Article XX and the WTO system allows its Members to use trade tools to pursue these objectives, even if the cost is an inconsistency with WTO market access rules. In its very first report, the Appellate Body called for coherence and famously cautioned against reading WTO law in "clinical isolation" from general (non-WTO) international law. The AB was widely lauded for having managed to appropriately "connect" the WTO system to the rest of international law. The $\mathrm{AB}$ Reports that deal with non-trade concerns, process and production methods ('PPMs'), and regulatory distinctions have been widely recognized as important contributions to promoting international regulatory coherence.

Another important principle of the WTO has been its consensus decisionmaking. In fact, consensus is only a practice because the WTO treaty has several sophisticated voting rules by steps, in addition to the simple majority voting. But many WTO Members (and in particular developed countries) favour consensus because it somehow depoliticizes voting issues and avoids NorthSouth voting, at least on some issues. This practice also emphasizes the fundamental principle that all WTO Members, from the smallest to largest, are equal. All WTO decisions are therefore taken by consensus, and each Member has the ability to block consensus. Even if the ability to withhold consensus is in practice more difficult to exercise for smaller less influential Members in the WTO, compared with the IMF and the World Bank-both of which use weighted voting to take decisions, the WTO has become developing countries' preferred ground-a "safe harbour" where their voices are equal to those of economically more influential countries. Indeed, in the 2005 WTO Ministerial Declaration, a decision called on the international financial institutions (eg, 
the IMF and the World Bank) not to impose conditionalities on least developed countries ('LDCs') that would be inconsistent with rights and obligations under the WTO system and seemed to provide the WTO with some form of role in this regard!

Today the WTO faces challenges from multiple fronts, and even its most fundamental principles are being challenged. Consensus decision-making has become a burden for Members that want to expand the WTO rules into new areas but face opposition from other Members. At the end of 2019, the functioning of the $\mathrm{AB}$ was suspended. Even more fundamental, in recent weeks, the logic and benefits of the MFN rule have been publicly contested. Intentions not to respect the non-discrimination principle have been openly and unambiguously expressed. Finally, the "developing country status" of some WTO Members has become a hotly debated issue. The United States and the EU argue that certain emerging economies have refused to recognize their new economic weight and assume the obligations that should accompany this. A war of words and threats between important players has started brewing.

The coronavirus pandemic may discourage some international exchanges, at least in the short term, but trade will necessarily continue. The WTO plays a vital role in trade governance and the administration of special trade concerns which are among the main goals of the GATT/WTO. But the dissatisfaction of certain Members with the current multilateral trading system is important and could prove fatal to the Organization. At the same time, in the same way as occurred during the GATT years, WTO Members should be encouraged to respond with real creativity to the current challenges.

For example, to address concerns that consensus decision-making slows down and even strangles the WTO, some have suggested that it may be time to return to the methods used during the Tokyo Round with "codes" that bind only those that wished to be bound and that can be adopted without the need for a consensus decision. New forms of decision-making are also being explored to alleviate the need to obtain the near-impossible consensus. Agreements negotiated by a sub-group of WTO Members but which, to be WTO consistent, provide benefits to all WTO Members, are economically viable if they involve a critical mass of WTO Members. Thus, for instance, at the (2017) Buenos Aires Conference, several WTO Members initiated the "Plurilateral Joint Initiatives" ('PJI'), whereby only a subgroup of Members agree to negotiate in new areas. At the moment, governments are exploring how to integrate these new important plurilateral commitments into the WTO legal system and the implications for non-participants. One thing is clear-there is no "backtracking" possible! The new PJI-type agreements have succeeded in advancing 
stalled trade negotiations, including in new sectors such as e-commerce and investment facilitation and their success has encouraged more WTO Members to join them.

To address the issue of developing country status, WTO Members have also shown creativity. Traditionally, developing country status has been selfdeclared in GATT/WTO. Now this approach is challenged by many, although all Members agree that LDCs deserve special treatment. This is a complex issue, with comparisons of global and per capita GDP clashing without effective solutions. Yet, the issue is fundamental. Indeed, what would be left of the principle of equality, if nine tenths $(9 / 10)$ of the members of an international organization can claim to have a right to not respect the rules and, at the same time, be entitled to claim special treatment? But in this war of words, Norway and others have intervened in the systemic battle and suggested pragmatic and ad hoc solutions. Forget the theories and principles! Rather, when WTO Members negotiate new provisions or agreements, the possibility of differentiation could be opened on an ad hoc basis. This new approach was used in the recent Trade Facilitation Agreement, which, borrowing a mechanism developed in multilateral environmental agreements, allows WTO Members to implement their TFA commitments in different timeframes depending on their level of development, and subject to receiving financial support from other Members. China, for example, committed to respect all TFA obligations in the same way as developed countries. Ad hoc solutions could be negotiated on a case-bycase basis, with no reference to any "principle" or developed or developing, only pragmatic solutions.

To address the impasse relating to the $\mathrm{AB}$, the $\mathrm{EU}$, China, and several other Members have engaged in a deep and far-reaching review of dispute settlement practices and interpretations. In fact, in the 12 months of the Walker process under the WTO reform efforts, WTO Members did more than during the 22 years of the DSU review exercise! Moreover, some 19 Members have suggested a new Appeal Arbitration mechanism during the interim period until the $A B$ is back in place. These collective creative efforts could result in better adapting the dispute settlement system to the requirements of today and tomorrow.

Finally, to allow for more flexibility in light of the WTO's growing membership and its very diverse needs, I would suggest an increased use of "scheduled" commitments that would allow each Member to provide more adapted commitments - as was done in the context of agriculture subsidies, GATS and the Government Procurement Agreement ('GPA'). An increased use of schedules of commitments, in which WTO Members could add terms, conditions, and qualifications as they traditionally have done with tariff bindings (this is 
also done under the WTO in the agriculture and services sectors) would provide more flexibility. Another possibility would include the use of (partial) reservations (totally absent in the WTO Agreement) and could also bridge the gap between traditional (absolute) MFN and commitments that would be better adapted "between countries where the same conditions prevail" - the standard used in GATT for non-trade concerns.

This is not the first time that international law has moved away from traditional rules in a way that facilitates greater participation in multilateral treaties without watering them down to the lowest common denomination-albeit at the expense of uniformity of obligations among member states.

In sum, the WTO crisis could provide an invaluable opportunity for Members to transform the international trade system and allow for new and better adapted rules in this era of digital globalization. In the last two years, more than 200 proposals in more than 10 sectors, including fundamental institutional reforms, have been put forward by WTO Members. WTO reforms are not just about its dispute settlement system; rather WTO reform relates to a large array of matters that concern international trade today. This WTO introspection calls for questions to be addressed from different perspectives, and for new approaches to be developed beyond the traditional legal and economic binary approach that has governed so much of trade policy. All these creative solutions may reflect moves (further) away from uniformity of obligations among WTO Members. 